\title{
Reproductive characteristics of the sole Achirus mazatlanus (Pleuronectiformes: Achiridae) in the Barra de Navidad coastal lagoon, Jalisco, Mexico
}

\section{Aspectos reproductivos del lenguado Achirus mazatlanus (Pleuronectiformes: Achiridae) en la laguna costera de Barra de Navidad, Jalisco, México}

\author{
Gabriela Lucano-Ramírez ${ }^{1}$, Miguel de Jesús Gómez-García ${ }^{1}$, Salvador Ruiz-Ramírez ${ }^{1 *}$, Gaspar \\ González-Sansón $^{1,2}$, Consuelo Aguilar-Betancourt ${ }^{1,2}$, Juan Ramón Flores-Ortega ${ }^{3}$ \\ ${ }^{1}$ Departamento de Estudios para el Desarrollo Sustentable de Zonas Costeras, Universidad de Guadalajara, \\ Valentín Gómez Farías 82, CP 48980, San Patricio-Melaque, Jalisco, Mexico. \\ 2 Canadian Rivers Institute, 100 Tucker Park Rd, Saint John, NB E2L 4A6, Canada. \\ ${ }^{3}$ Escuela Nacional de Ingeniería Pesquera, Universidad Autónoma de Nayarit, Bahía de Matanchén km. 12, \\ Carretera a los Cocos, CP 63740, San Blas, Nayarit, Mexico. \\ * Corresponding author. E-mail: sruizram@costera.melaque.udg.mx
}

\begin{abstract}
Achirus mazatlanus is one of the most widely distributed and abundant soles occurring on the Pacific coast of Mexico, yet most of its biological and reproductive characteristics are unknown. Weekly and monthly samples were collected in the Barra de Navidad coastal lagoon (Jalisco, Mexico) from February 2011 to August 2016 to assess the reproductive biology of this species. Observed total sex ratio (F1.00:M1.03) was not significantly different from the expected 1:1 ratio. Females were, on average, larger than males. The observed monthly gonadosomatic index, percentage of mature gonads, mean oocyte diameter, and ovarian-wall thickness suggest that the species reproduces year-round, with an important reproductive season lasting from April to August. Females were classified as partial spawners with asynchronous oocyte development, and males showed unrestricted spermatogonial testes. The presence of spawned individuals and hydrated oocytes in certain months indicates that the species could be spawning in the lagoon; however, the occurrence of eggs and larvae needs to be demonstrated to ascertain this statement. This was the first time length at sexual maturity was assessed for female $(10.84 \mathrm{~cm})$ and male $(10.23 \mathrm{~cm})$ A. mazatlanus.
\end{abstract}

Key words: Achiridae, reproduction, length at sexual maturity, coastal lagoon, Pacific coast of Mexico.

RESUMEN. Achirus mazatlanus es uno de los peces planos más abundantes de la costa mexicana del Pacífico, pero la mayoría de sus aspectos biológicos y reproductivos se desconocen. Se realizaron muestreos semanales y mensuales en la laguna costera de Barra de Navidad (Jalisco, México) de febrero de 2011 a agosto de 2016 con el fin de conocer la biología reproductiva de esta especie. La proporción sexual (H:M) total (1.00:1.03) no difírió de la relación esperada de 1:1. Las hembras fueron, en promedio, más grandes que los machos. Los resultados observados para el índice gonadosomático mensual, el porcentaje de gónadas maduras, el diámetro medio de los ovocitos y el grosor de la pared ovárica sugieren que la especie se reproduce durante todo el año, con una estación reproductiva importante de abril a agosto. Las hembras fueron clasificadas como desovadoras parciales con desarrollo asincrónico de los ovocitos. Los machos presentaron testículos con desarrollo espermatogonial sin restricción. Debido a que se observaron individuos maduros y ovocitos hidratados durante ciertos meses, la especie puede estar desovando dentro de la laguna; sin embargo, sería necesario demostrar la presencia de huevos y larvas para asegurar esto. Por primera vez, se calculó la longitud de madurez sexual para las hembras $(10.84 \mathrm{~cm})$ y los machos $(10.23 \mathrm{~cm})$ de A. mazatlanus.

Palabras clave: Achiridae, reproducción, longitud de madurez, laguna costera, costa mexicana del Pacífico.

\section{INTRODUCTION}

Many tropical fish have adapted their reproductive strategies to the low environmental variability in their habitats and have opted for longer reproductive periods with multiple spawning events (Lowe-McConnell 1987). Tropical Pleuronectiformes species have shown long or nearly year-round reproductive periods (Gibson 2008).

The Achiridae family, also known as American soles, is one of the most abundant and least studied taxa of the order Pleuronectiformes. It includes 7 genera and 29 species (Robertson and Allen 2015). The sole Achirus mazatlanus (Steindachner, 1869), or Mexican sole, is a pelagic spawner

\section{INTRODUCCIÓN}

Muchos peces tropicales han adaptado sus estrategias reproductivas a la poca variabilidad ambiental de su medio, y han optado por periodos reproductivos más amplios y múltiples eventos de desove (Lowe-McConnell 1987). Los pleuronectiformes de ambientes tropicales han mostrado periodos reproductivos amplios o durante gran parte del año (Gibson 2008).

Uno de los taxones más abundantes y menos estudiados del orden Pleuronectiformes es la familia Achiridae, conocida como soles americanos. Cuenta con 7 géneros y 29 especies (Robertson y Allen 2015). El lenguado Achirus mazatlanus 
that uses estuarine systems as habitats for nursing and development, and it is distributed from Baja California to Peru (Krupp 1995).

Achirus mazatlanus is the most abundant sole in the Barra de Navidad coastal lagoon (Jalisco, Mexico), where it reaches $22 \mathrm{~cm}$ in length (González-Sansón et al. 2014). The fact that this species is abundant, easy to catch, and continuously present in the system has arisen interest in the use of this species as a bioindicator of pollution in the lagoon (Aguilar-Betancourt et al. 2016). Despite its abundance and wide distribution range, there are few studies about this species, and it is only mentioned in systematic lists (e.g., Aguilar-Palomino et al. 2001, Lucano-Ramírez et al. 2001), in a study reporting its feeding habits and some information about its reproduction (Amezcua-Linares et al. 1992), and in studies reporting its taxonomic characteristics (Ortíz-Galindo et al. 1990, Gracian-Negrete and Del Moral-Flores 2013).

In view of all the above, and to partially fill in the glaring gaps in the information available for species, this study describes the reproductive characteristics of $A$. mazatlanus in the Barra de Navidad coastal lagoon, Jalisco, Mexico.

\section{MATERIALS AND METHODS}

Samples were obtained from the Barra de Navidad coastal lagoon, on the southern coast of Jalisco, Mexico $\left(19^{\circ} 11^{\prime} 25^{\prime \prime} \mathrm{N}, 104^{\circ} 39^{\prime} 53^{\prime \prime} \mathrm{W}\right)$. This lagoon is permanently connected to Navidad Bay, allowing for port activities, tourism, and commerce. Moreover, the lagoon is part of the Laguna Barra de Navidad wetland, which consists of 382 ha of surface water, with seasonal inputs of fresh water from the Arroyo Seco and Marabasco rivers, and 620 ha of mangrove forest, the second largest mangrove forest in Jalisco (CONANP 2008).

Specimens were collected during weekly samplings from February 2011 to March 2012 and monthly samplings from April 2012 to August 2016. They were caught by one of 3 types of fishing gear: a beach seine net with a mesh size of $1 \mathrm{~cm}$ ( 5 casts at 2 sites, north beach and south beach, from 16:00 to 19:30), a cast net $3 \mathrm{~m}$ in diameter with a mesh size of $2.5 \mathrm{~cm}$ (40-50 casts at random sites from 16:00 to 19:30), and a trawl net measuring $5 \mathrm{~m}$ at the mouth with a mesh size of $2.5 \mathrm{~cm}$ ( 2 tows at 8 sites from 03:00 to 07:00). Each specimen was measured for total length $(\mathrm{TL}, \pm 0.1 \mathrm{~cm})$ and total weight (TW, $\pm 0.1 \mathrm{~g}$ ). The gonads were extracted and weighed $( \pm 0.01 \mathrm{~g})$, and sex was determined. Gonads were assigned a maturity stage following Everson et al. (1989). All gonads were fixed in neutral formalin.

For histological analyses, we processed a sample from each ovary $(n=96)$ but processed whole testes $(n=121)$. Samples were dehydrated, embedded in paraffin (Paraplast, Leica; Richmond, USA), sliced ( $6 \mu \mathrm{m}$-thick sections), stained with haematoxylin-eosin, and preserved in Canada balsam.
(Steindachner, 1869), o sol mexicano, es desovador pelágico, utiliza sistemas estuarinos como hábitat de crianza y desarrollo, y se distribuye desde Baja California hasta Perú (Krupp 1995).

Achirus mazatlanus es el lenguado más abundante de la laguna costera de Barra de Navidad (Jalisco, México), donde alcanza tallas de $22 \mathrm{~cm}$ (González-Sansón et al. 2014). Su abundancia, fácil captura y permanencia en el sistema han despertado el interés de utilizar la especie como potencial bioindicador de contaminación en la laguna (Aguilar-Betancourt et al. 2016). A pesar de su abundancia y amplia distribución, existen pocos estudios de la especie, y solo se menciona en listados sistemáticos (e.g., Aguilar-Palomino et al. 2001, Lucano-Ramírez et al. 2001), en un estudio de alimentación e información parcial de la reproducción (Amezcua-Linares et al. 1992) y en estudios de aspectos taxonómicos (Ortíz-Galindo et al. 1990, Gracian-Negrete y Del Moral-Flores 2013).

Por lo anterior, y con la finalidad de llenar parte del vacío de información tan evidente de esta especie, se describen aspectos reproductivos de $A$. mazatlanus de la laguna costera de Barra de Navidad, Jalisco, México.

\section{MATERIALES Y MÉTODOS}

Las muestras se obtuvieron de la laguna costera de Barra de Navidad, en la costa sur de Jalisco, México $\left(19^{\circ} 11^{\prime} 25^{\prime \prime} \mathrm{N}\right.$, $\left.104^{\circ} 39^{\prime} 53^{\prime \prime} \mathrm{W}\right)$. Esta laguna se comunica permanentemente con la bahía de Navidad, lo que permite actividades portuarias, turísticas y comerciales. Además, la laguna forma parte del humedal Laguna Barra de Navidad, el cual consta de 382 ha de espejo de agua, con entradas temporales de agua dulce de los ríos Arroyo Seco y Marabasco, y de 620 ha de manglar, el segundo manglar más extenso de Jalisco (CONANP 2008).

Los organismos fueron obtenidos a partir de muestreos semanales de febrero de 2011 a marzo de 2012 y muestreos mensuales de abril de 2012 a agosto de 2016. Fueron capturados con uno de 3 tipos de arte pesca: un chinchorro playero de $1 \mathrm{~cm}$ de luz de malla (5 lances en 2 sitios, playa norte y playa sur, de 16:00 a 19:30), una atarraya de $3 \mathrm{~m}$ de diámetro y $2.5 \mathrm{~cm}$ de luz de malla (40-50 lances en sitios aleatorios de 16:00 a 19:30) y una red de arrastre de $5 \mathrm{~m}$ en la boca y $2.5 \mathrm{~cm}$ de luz de malla ( 2 arrastres en 8 sitios de 03:00 a 07:00). Para cada individuo, se registró la longitud total (LT, $\pm 0.1 \mathrm{~cm}$ ) y el peso total $(\mathrm{PT}, \pm 0.1 \mathrm{~g})$. También, se extrajeron y pesaron $( \pm 0.01 \mathrm{~g})$ las gónadas, y se determinó el sexo. A las gónadas se les asignó el estadio de madurez de acuerdo con Everson et al. (1989). Las gónadas fueron conservadas en formol neutro.

Para el análisis histológico, se procesó una muestra de cada ovario $(n=96)$, mientras que el testículo se procesó completo $(n=121)$. Las muestras fueron deshidratas, incluidas en parafina (Paraplast, Leica; Richmond, EUA), 
Ten sections per maturity stage were chosen for every month. We measured 10 oocytes (with visible nucleus) from every phase present in these sections; in addition, we measured ovarian wall thickness at 3 random points using a digital camera (AxioCam ERc5s, Zeiss; Oberkochen, Germany) mounted on a microscope (Axiostar, Zeiss; Oberkochen, Germany). Oocytes were classified according to Yamamoto and Yamazaki (1961) and Brown-Peterson et al. (2011), and testes were classified according to García-López et al. (2005).

A typical year was determined. We determined sex ratio by month and by length class using the total number of specimens. The chi squared $\left(\chi^{2}\right)$ test was used to determine significant differences from the expected 1:1 ratio. We determined the gonadosomatic index (GSI; GSI = [gonadal weight $/ \mathrm{TW}] \times 100$ ), relative condition factor $(\mathrm{CF}$; $\left.\mathrm{CF}=\left[\mathrm{TW} / \mathrm{TL}^{3.2}\right] \times 100\right)$, and average length at sexual maturity $\left(\mathrm{L}_{50}\right)$, which was estimated by performing a nonlinear fit to the $\mathrm{P}_{\mathrm{TL}}=1 /\left[1+\mathrm{e}^{(b \mathrm{TL}+a)}\right] \times 100$ logistic model, where $\mathrm{P}_{\mathrm{TL}}$ is the percentage of mature individuals at TL, and $a$ and $b$ are the parameters of the fitted curve.

Student's $t$ test was used to determine significant differences between lengths of females and males. The one-way analysis of variance (ANOVA) was used to examine differences between monthly values. When significant values were obtained, a post hoc Student-Newman-Keuls (SNK) test was run to determine homogenous groups. Spearman's correlation $\left(r_{s}\right)$ was carried out. All statistical analyses were performed using a significance level of 0.05 and STATISTICA v.7.1 (StatSoft 2006).

\section{Results}

\section{Size composition and sex ratio}

A total of 1,321 specimens of A. mazatlanus were analyzed. Average TL was $14.30 \mathrm{~cm}( \pm 0.08)$, with a minimum of $1.4 \mathrm{~cm}$ and a maximum of $23 \mathrm{~cm}$. We recorded 518 females (average $\mathrm{TL}=15.39 \mathrm{~cm}, \pm 0.10$ ), 531 males (average $\mathrm{TL}=$ $14.14 \mathrm{~cm}, \pm 0.07)$, and 272 specimens with unidentified sex. Females were larger than males $\left(t_{1,1,048}=10.04, P=0.031\right)$. The smallest female and male measured 6.1 and $6.0 \mathrm{~cm}$, respectively. Males showed higher frequencies in 2 length classes (13 and $15 \mathrm{~cm}$ ), whereas females showed higher frequencies in 4 length classes $(11,17,19$, and $21 \mathrm{~cm})$ (Fig. 1). The sex ratio (F:M) showed no differences for the total sample $(1.00: 1.03)\left(\chi^{2}=0.16, P=0.68\right)$; however, the ratio was significantly biased toward males in February (1.0:1.7), July (1.0:1.4), and August (1.0:2.0) and significantly biased toward females in September (1.0:0.2). In addition, the ratio was significantly different among size classes; males were dominant in the $13 \mathrm{~cm}(1.0: 2.2)$ and $15 \mathrm{~cm}(1.0: 1.3)$ length classes, whereas females were dominant in the $17 \mathrm{~cm}(1.0: 0.3), 19 \mathrm{~cm}(1.0: 0.1)$, and $21 \mathrm{~cm}$ (1.0:0.3) length classes. cortadas ( $6 \mu \mathrm{m}$ de grosor), teñidas con hematoxilina-eosina y preservadas con bálsamo de Canadá.

Mensualmente, se eligieron 10 cortes por estadio de madurez. De estos cortes, se midieron 10 ovocitos (con núcleo visible) de cada fase encontrada; además, se midió el grosor de la túnica ovárica en 3 puntos aleatorios. Las medidas se realizaron con una cámara digital (AxioCam ERc5s, Zeiss; Oberkochen, Alemania) acoplada a un microscopio (Axiostar, Zeiss; Oberkochen, Alemania). Los ovocitos fueron clasificados según Yamamoto y Yamazaki (1961) y Brown-Peterson et al. (2011), y los testículos fueron clasificados según GarcíaLópez et al. (2005).

Se generó un año tipo. Se obtuvo la proporción sexual mensual y por clase de longitud para el total de organismos. La prueba estadística chi cuadrada $\left(\chi^{2}\right)$ fue utilizada para comprobar diferencias significativas en la proporción 1:1. Se calculó el índice gonadosomático (IGS; IGS $=$ [peso gonadal/PT] $\times 100$ ), el factor de condición $(\mathrm{FC})$ relativo $\left(\mathrm{FC}=\left[\mathrm{PT} / \mathrm{LT}^{3.2}\right] \times 100\right)$ y la longitud promedio de madurez sexual $\left(\mathrm{L}_{50}\right)$, estimada mediante un ajuste no lineal al modelo logístico $\mathrm{P}_{\mathrm{LT}}=1 /\left[1+\mathrm{e}^{(b \mathrm{LT}+a)}\right] \times 100$, donde $\mathrm{P}_{\mathrm{LT}}$ es el porcentaje de individuos maduros a la LT, y $a$ y $b$ son parámetros de la curva ajustada.

La prueba $t$ de Student fue utilizada para comprobar diferencias entre las longitudes de las hembras y los machos. Se realizó el análisis de varianza (ANDEVA) de una vía para examinar las diferencias entre los valores mensuales. En caso de obtener valores significativos, se realizó la prueba post hoc de Student-Newman-Keuls (SNK) para determinar grupos homogéneos. Se realizaron análisis de correlación de Spearman $\left(r_{s}\right)$. Para todos los análisis estadísticos, se utilizó un nivel de significación de 0.05 y el programa STATISTICA v.7.1 (StatSoft 2006).

\section{Resultados}

\section{Composición por talla y proporción sexual}

Se analizaron 1,321 individuos de A. mazatlanus. La LT promedio fue de $14.30 \mathrm{~cm}( \pm 0.08)$, la mínima de $1.4 \mathrm{~cm}$ y la máxima de $23 \mathrm{~cm}$. Se registraron 518 hembras (LT promedio $=$ $15.39 \mathrm{~cm}, \pm 0.10$ ), 531 machos (LT promedio $=14.14 \mathrm{~cm}$, $\pm 0.07)$ y 272 individuos indiferenciados. Las hembras fueron más grandes que los machos $\left(t_{1,1,048}=10.04, P=0.031\right)$. La hembra y el macho de menor longitud midieron $6.1 \mathrm{y}$ $6.0 \mathrm{~cm}$, respectivamente. Los machos presentaron mayores frecuencias en 2 clases de longitud $(13$ y $15 \mathrm{~cm})$, en tanto que las hembras en cuatro (11, 17, 19 y $21 \mathrm{~cm})$ (Fig. 1). No se observó diferencia en la proporción sexual (H:M) para la muestra total (1.00:1.03) $\left(\chi^{2}=0.16, P=0.68\right)$; sin embargo, la proporción estuvo significativamente sesgada hacia los machos en febrero (1.0:1.7), julio (1.0:1.4) y agosto (1.0:2.0) y significativamente sesgada hacia las hembras en septiembre (1.0:0.2). La proporción también mostró diferencias significativas en las clases de talla; los machos dominaron en las 


\section{Monthly variation in the gonadosomatic index}

Significant differences were observed in the monthly average values of female GSI $\left(F_{11,380}=3.82, P=0.021\right)$ and male GSI $\left(F_{11,380}=3.82, P=0.021\right)$ (Fig. 2$)$. In the case of females, paired comparisons showed 5 overlapping groups. August showed the maximum value (2.96 \pm 0.75 , letter $E$ in Fig. 2) and September the minimum value $(0.79 \pm 0.13$, letter $A$ in Fig. 2$)$; the highest GSI values occurred between April (2.67 \pm 0.18$)$ and August. In the case of males, paired comparisons showed 2 overlapping groups. January $(0.11 \pm 0.01)$, March $(0.11 \pm 0.02)$, April $(0.10 \pm 0.01)$, and June $(0.13 \pm 0.02)$ showed minimum values (number 1 in Fig. 2), and November showed the maximum value $(0.21 \pm 0.02$, number 2 in Fig. 2$)$.

\section{Monthly variation in the condition factor}

Significant differences were observed in the monthly average $C F$ values for females $\left(F_{11,501}=9.17, P=0.001\right)$ and males $\left(F_{11,504}=55.7, P=0.005\right)$ (Fig. 3). Paired comparisons showed 5 groups for both females and males, with an overlap in both cases. The maximum average values occurred in May for females (1.14 \pm 0.03 , letter $E$ in Fig. 3) and males $(1.09 \pm 0.04$, number 5 in Fig. 3$)$; the minimum average values occurred in August $(0.98 \pm 0.01$, letter $A$ in Fig. 3) for females and in January $(0.98 \pm 0.01$, number 1 in Fig. 3) and March (0.98 \pm 0.02 , number 1 in Fig. 3) for males. The $\mathrm{CF}$ of males and females showed a significant correlation $\left(r_{s}=0.75, P=0.005, n=12\right)$. No correlation was observed between CF and GSI for males $\left(r_{s}=0.27\right.$, $P=0.396, n=12)$ or for females $\left(r_{s}=-0.18, P=0.575\right.$, $n=12)$.

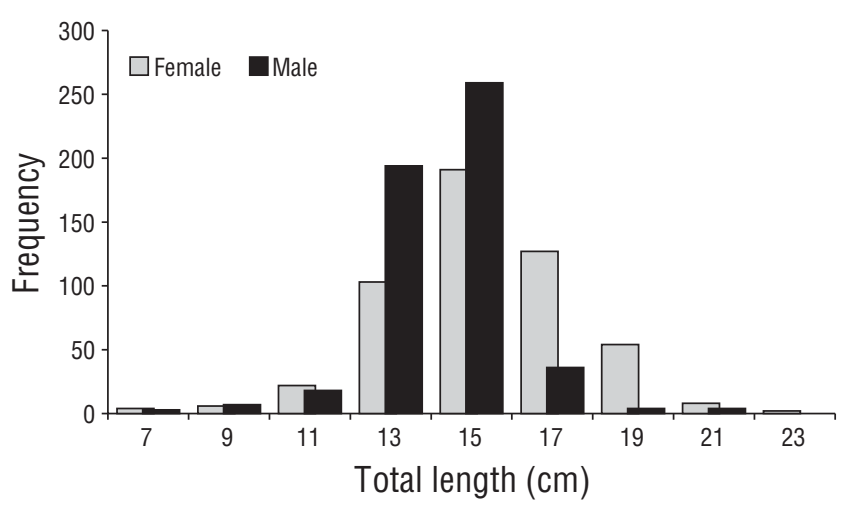

Figure 1. Frequency distribution of total length of female and male Achirus mazatlanus in the Barra de Navidad coastal lagoon, Jalisco, Mexico.

Figura 1. Distribución de frecuencia de la longitud total de hembras y machos de Achirus mazatlanus en la laguna costera de Barra de Navidad, Jalisco, México. clases de $13 \mathrm{~cm}(1.0: 2.2)$ y $15 \mathrm{~cm}(1.0: 1.3)$, mientras que las hembras dominaron en las clases de $17 \mathrm{~cm}(1.0: 0.3), 19 \mathrm{~cm}$ (1.0:0.1) y $21 \mathrm{~cm}(1.0: 0.3)$.

\section{Variación mensual del índice gonadosomático}

Se encontraron diferencias significativas en los valores promedio mensuales del IGS de hembras $\left(F_{11,376}=7.03, P=\right.$ $0.002)$ y de machos $\left(F_{11,380}=3.82, P=0.021\right)$ (Fig. 2). Para las hembras, las comparaciones por pares indicaron 5 grupos con traslapo. Agosto presentó el valor máximo (2.96 \pm 0.75 , letra $E$ en Fig. 2) y septiembre el mínimo $(0.79 \pm 0.13$, letra $A$ en Fig. 2); los mayores valores del IGS ocurrieron entre abril $(2.67 \pm 0.18)$ y agosto. Para los machos, la prueba por pares indicó 2 grupos con traslapo. Enero $(0.11 \pm 0.01)$, marzo $(0.11 \pm 0.02)$, abril $(0.10 \pm 0.01)$ y junio $(0.13 \pm 0.02)$ presentaron valores mínimos (número 1 en Fig. 2), y noviembre presentó el valor máximo (0.21 \pm 0.02 , número 2 en Fig. 2).

\section{Variación mensual del factor de condición}

Se encontraron diferencias significativas en los valores promedio mensuales del FC de hembras $\left(F_{11,501}=9.17, P=\right.$ $0.001)$ y de machos $\left(F_{11,504}=55.7, P=0.005\right)$ (Fig. 3$)$. Las comparaciones por pares indicaron 5 grupos tanto en hembras como en machos, en ambos casos con traslapo. El promedio máximo se presentó en mayo para las hembras $(1.14 \pm 0.03$, letra $E$ en Fig. 3) y los machos (1.09 \pm 0.04 , número 5 en Fig. 3); el promedio mínimo para las hembras se presentó en agosto $(0.98 \pm 0.01$, letra $A$ en Fig. 3$)$ y para los machos en enero $(0.98 \pm 0.01$, número 1 en Fig. 3$)$ y marzo $(0.98 \pm 0.02$, número 1 en Fig. 3). Se encontró correlación significativa entre el FC de machos y hembras $\left(r_{s}=0.75, P=0.005\right.$, $n=12)$. No se observó correlación entre el FC y el IGS ni para los machos $\left(r_{s}=0.27, P=0.396, n=12\right)$ ni para las hembras $\left(r_{s}=-0.18, P=0.575, n=12\right)$.

\section{Descripción de las gónadas}

Las gónadas se encontraron en la cavidad ventral. Los ovarios, que penetraron entre el músculo y las espinas de la aleta anal, formaron estructuras pareadas alargadas con aspecto de liso a granuloso. En los estadios avanzados de madurez se extendieron hasta la mitad de la aleta anal. Los ovarios inmaduros fueron de color claro, tamaño pequeño y aspecto flácido. Al madurar, aumentaron su tamaño y firmeza, y cambiaron de color amarillo a color rojizo. Los testículos fueron pequeños, de forma redondeada y de color variable de rojizo a blanco amarillento. Su turgencia fue mayor conforme fueron madurando.

Los ovocitos dentro del ovario fueron diferenciándose en cada una de las distintas fases de maduración. Al inicio, el ovario presentó solo ovocitos en crecimiento primario (Fig. 4a). Estos ovocitos fueron madurando a diferente tiempo; es decir, presentaron desarrollo asincrónico dentro del ovario 


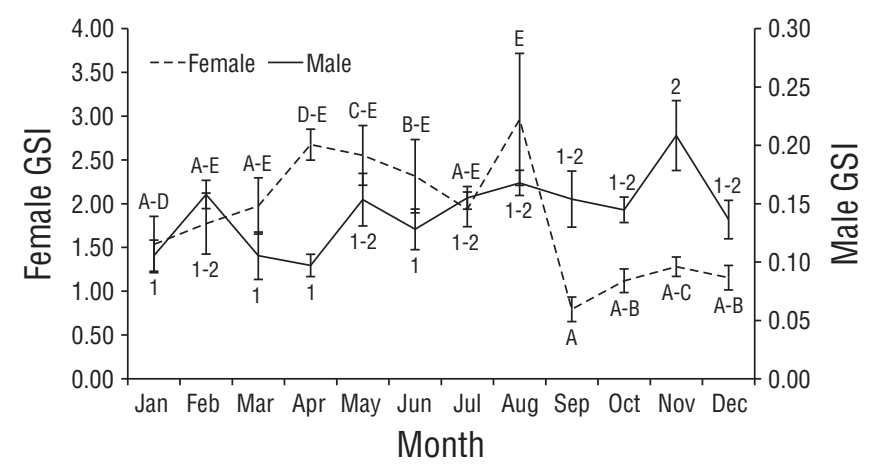

Figure 2. Monthly variation of the gonadosomatic index (GSI) for female and male (mean \pm standard error) Achirus mazatlanus in the Barra de Navidad coastal lagoon, Jalisco, Mexico. Different letters (females) and numbers (males) indicate significant differences.

Figura 2. Variación mensual del índice gonadosomático (GSI) para hembras y machos (media \pm error estándar) de Achirus mazatlanus en la laguna costera de Barra de Navidad, Jalisco, México. Las letras (hembras) y números (machos) diferentes indican diferencias significativas.

\section{Gonad description}

Gonads were found in the ventral cavity. Ovaries, which were located between the muscle and anal fin bones, formed long paired structures with smooth to granular surfaces. They extended to the middle of the anal fin in the more advanced maturity stages. Immature ovaries were pale in color, small, and flaccid. As they matured, they became larger and firmer, and changed from a yellow to a reddish color. Testes were small, round in shape, and reddish to yellowish-white in color. Turgidity increased with maturity.

Oocyte differentiation in the ovaries occurred in all developing phases. At first, the ovary showed only primary growth oocytes (Fig. 4a). These oocytes matured at different times; that is, oocyte development in the ovaries was asynchronous (Fig. 4b) until reaching advanced maturation phases, which included oocytes with germinal vesicle migration, oocytes with germinal vesicle breakdown, or hydrated oocytes (Fig. 4c, d). Testes showed spermatogenic development throughout the tissue (Fig. 5a). Spermatogonia originated in the cortex and continued to develop in the lobules as testes matured (Fig. 5b), which is typical in unrestricted lobular testes development (Fig. 5 c). Nearly $50 \%$ of the 96 ovaries and 121 testes analyzed showed melanomacrophage centers (Fig. 5d).

\section{Gonad maturity stages}

Females showed all 4 maturity stages throughout the year (except for immature females in December) (Fig. 6a). The highest percentages of mature females were found in March

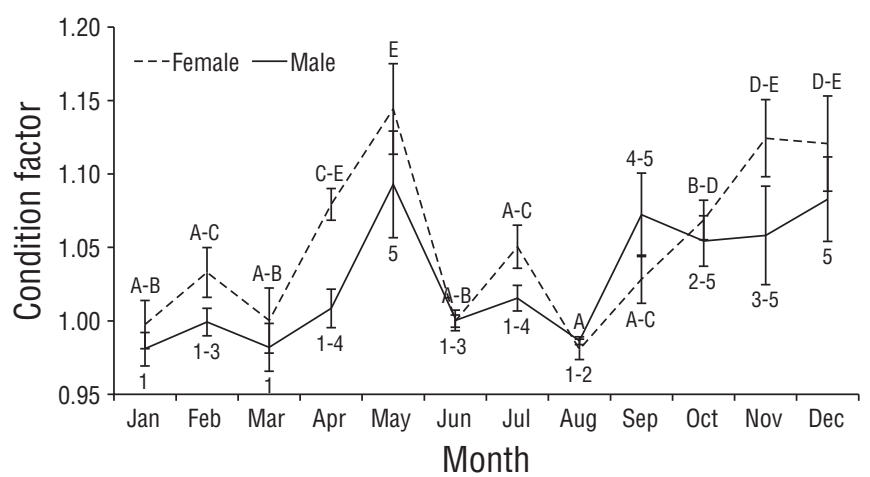

Figure 3. Monthly variation in the condition factor of female and male (mean \pm standard error) Achirus mazatlanus in the Barra de Navidad coastal lagoon, Jalisco, Mexico. Different letters (females) and numbers (males) indicate significant differences.

Figura 3. Variación mensual del factor condición de hembras y machos (media \pm error estándar) de Achirus mazatlanus en la laguna costera de Barra de Navidad, Jalisco, México. Las letras (hembras) y números (machos) diferentes indican diferencias significativas.

(Fig. 4b) hasta alcanzar las fases de maduración avanzada, que incluyen a los ovocitos con vesícula germinal migrada, ovocitos con ruptura de la vesícula germinal u ovocitos hidratados (Fig. 4c, d). Los testículos presentaron desarrollo espermatogénico a lo largo de todo el tejido (Fig. 5a). Las espermatogonias se originaron en la corteza y se fueron desarrollando en los lóbulos conforme avanzó la madurez del testículo (Fig. 5b), lo cual es característico del testículo con desarrollo lobular no restringido (Fig. 5c). De los 96 ovarios y 121 testículos analizados, cerca del 50\% presentaron centros de melanomacrófagos (Fig. 5d).

\section{Estadios de madurez gonadal}

En las hembras se presentaron los 4 estadios de madurez durante todo el año (excepto en hembras inmaduras en diciembre) (Fig. 6a). Los mayores porcentajes de hembras maduras se encontraron en marzo y abril. La mayor actividad reproductiva ocurrió, en general, de enero a abril y de junio a agosto. En los machos también se observaron los 4 estadios de madurez, y los mayores porcentajes de organismos maduros se encontraron en febrero, marzo y junio-agosto (Fig. 6b).

\section{Diámetro de los ovocitos y grosor de la túnica ovárica}

El ANDEVA mostró diferencias significativas en el diámetro mensual de los ovocitos $\left(F_{11,941}=6.43, P<0.001\right)$. La prueba por pares mostró 2 grupos. En febrero y diciembre se registraron los diámetros menores, y en abril, junio, y agosto-octubre se registraron los promedios mayores; el resto de los meses se traslaparon con ambos grupos (Fig. 7). No se presentó correlación entre el diámetro de los ovocitos y el $\operatorname{IGS}\left(r_{s}=0.09, P=0.762, n=12\right)$. 
and April. In general, reproductive activity was highest from January to April and from June to August. Males also showed all 4 maturity stages, with the highest percentages of mature males occurring in February, March, and June-August (Fig. 6b).

\section{Oocyte diameter and ovarian wall thickness}

ANOVA showed significant differences in monthly oocyte diameters $\left(F_{11,941}=6.43, P<0.001\right)$. Paired comparisons showed 2 groups. The smallest diameters were recorded in February and December, and the highest averages were recorded in April, June, and August-October; all the other months showed an overlap between both groups (Fig. 7). No correlation was observed between oocyte diameter and GSI values $\left(r_{s}=0.09, P=0.762\right.$, $n=12)$.
También se observaron diferencias en el grosor de la túnica ovárica a lo largo del año $\left(F_{11,462}=7.67, P<0.001\right)$. La prueba de SNK mostró 3 grupos de grosores. Los valores máximos sin traslape se encontraron en noviembre y diciembre, y los mínimos en enero, abril-junio, agosto y septiembre; el resto de los meses presentaron traslapo entre los grupos. Se observó una correlación negativa entre el grosor de la túnica ovárica y el IGS $\left(r_{s}=-0.615, P=0.033, n=12\right)$.

\section{Longitud de madurez sexual}

La hembra madura de menor talla midió $7.1 \mathrm{~cm}$ de largo y el macho maduro más pequeño midió $9.4 \mathrm{~cm}$ de largo. Con base en el modelo de ajuste no lineal, la $\mathrm{L}_{50}$ fue de $11.26 \mathrm{y}$ $10.23 \mathrm{~cm}$ para hembras y machos, respectivamente (Fig. 8). Más del 90\% de las hembras y los machos se habían reproducido por lo menos una vez a los $17 \mathrm{~cm}$.
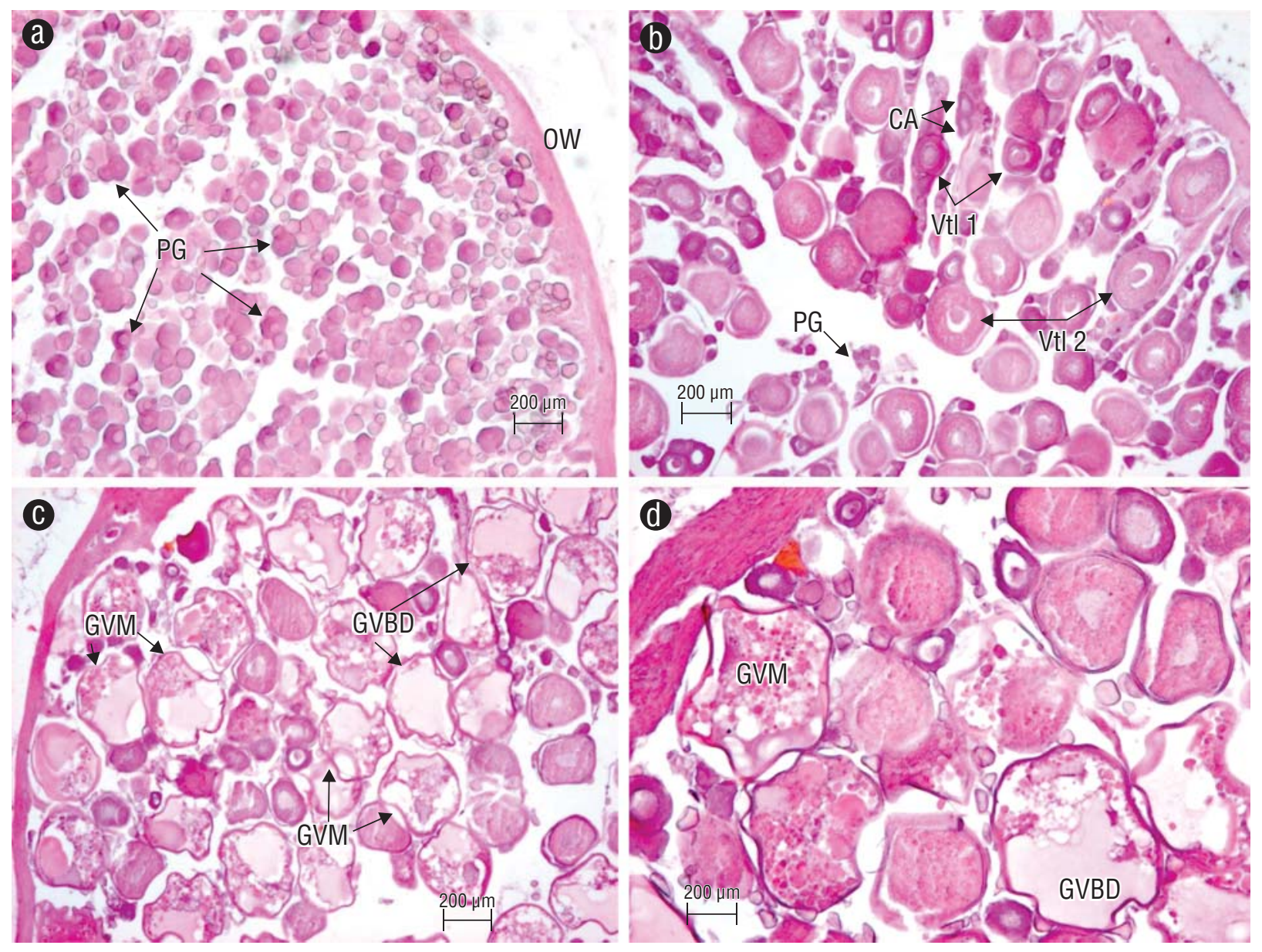

Figure 4. Achirus mazatlanus ovary with asynchronous oocyte development. (a) Oocytes in the primary growth (PG) phase and the ovarian wall (OW). (b) Oocytes during different developmental stages: oocytes in PG, cortical alveolus (CA), primary vitellogenesis (Vtl 1), and secondary vitellogenesis (Vtl 2). (c, d) Oocytes undergoing late germinal vesicle migration (GVM) and germinal vesicle breakdown (GVBD).

Figura 4. Ovario de Achirus mazatlanus con desarrollo de ovocitos asincrónico. (a) Ovocitos en fase de crecimiento primario (PG) y túnica ovárica (OW). (b) Ovocitos en distintas fases de desarrollo: ovocitos en PG, alveolos corticales (CA), vitelogénesis primaria (Vtl 1) y vitelogénesis secundaría (Vtl 2). (c, d) Ovocitos con migración tardía de la vesícula germinal (GVM) y vesícula germinal degradada (GVBD). 

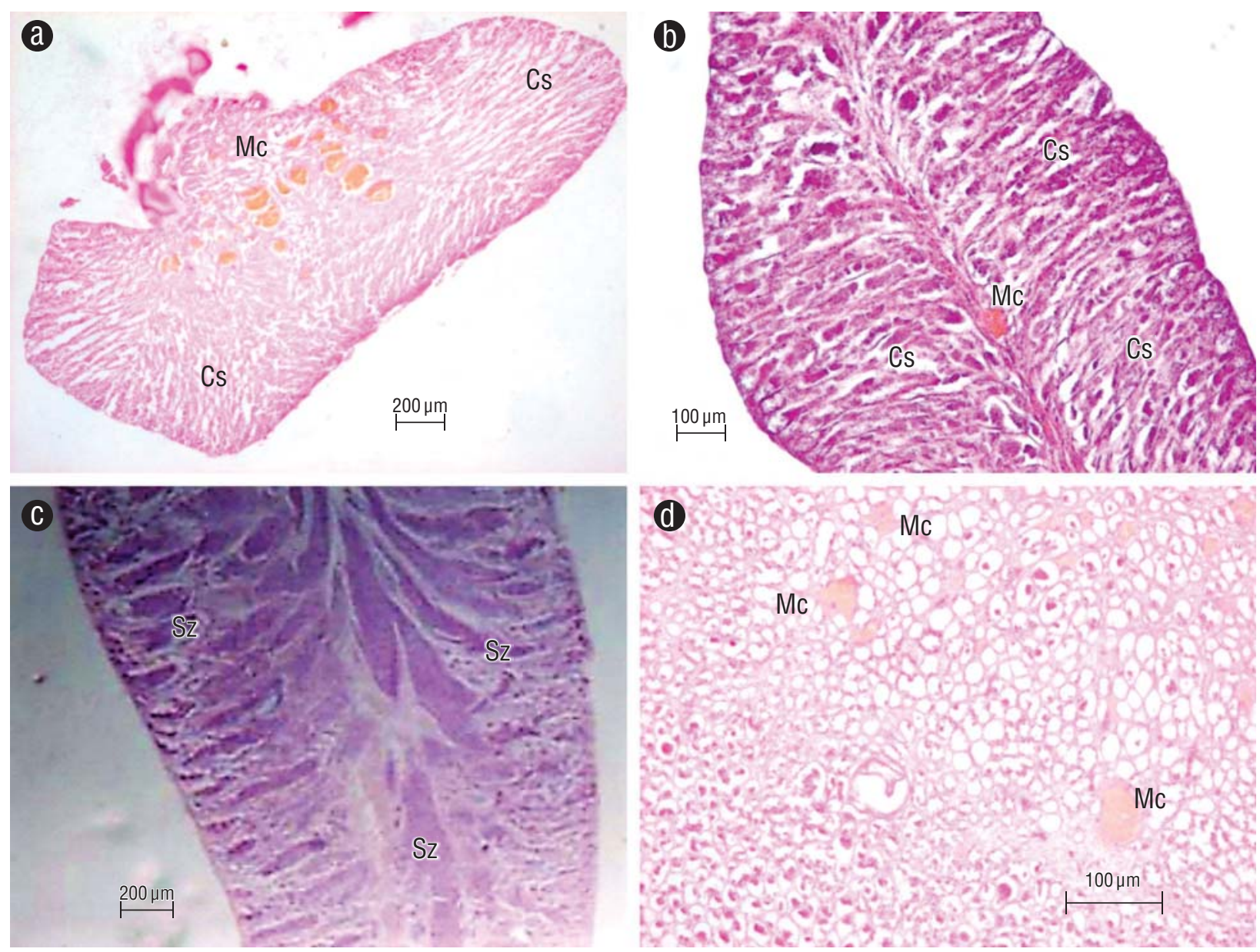

Figure 5. Achirus mazatlanus unrestricted lobular testes. (a, b) Immature testis with early spermatogenesis in cysts (Cs). (c) Mature testis with spermatozoa (Sz) in the lobules near the main duct. (d) Melanomacrophage centers (Mc).

Figura 5. Testículos con desarrollo lobular no restringido de Achirus mazatlanus. (a, b) Testículo inmaduro con espermatogénesis temprana en los cistos (Cs). (c) Testículo maduro con espermatozoides (Sz) en los lóbulos cerca del conducto principal. (d) Centros de melanomacrófagos $(\mathrm{Mc})$.

Ovarian wall thickness also exhibited differences throughout the year $\left(F_{11,462}=7.67, P<0.001\right)$. The SNK test showed 3 thickness groups. Maximum values with no overlap were observed in November and December, and minimum values were observed in January, April-June, August, and September; all the other months showed an overlap between groups. A negative correlation was observed between ovarian wall thickness and GSI values $\left(r_{s}=-0.615, P=0.033, n=12\right)$.

\section{Length at sexual maturity}

The smallest mature female was $7.1 \mathrm{~cm}$ long, and the smallest mature male was $9.4 \mathrm{~cm}$ long. According to the nonlinear regression model, $\mathrm{L}_{50}$ was 11.26 and $10.23 \mathrm{~cm}$ for females and males, respectively (Fig. 8). More than $90 \%$ of females and males measuring $17 \mathrm{~cm}$ in length had already reproduced at least once in their lifetime.

\section{Discusión}

Se ha mencionado que el dimorfismo sexual es frecuente en los pleuronectiformes (Gibson 2008). En este estudio, las hembras de A. mazatlanus fueron más grandes que los machos, lo cual también ha sido reportado por Gibson (2008) y Aguilar-Betancourt et al. (2016). Este dimorfismo puede deberse a que los machos apuestan más por un desarrollo y una madurez tempranos, lo cual es frecuente en los lenguados; en cambio, en las hembras, mientras mayor sea la longitud mayor será la fecundidad (Roff 1982). Los estudios recientes sobre la historia de vida de los pleuronectiformes sugieren que los machos pueden invertir poca energía en la maduración del testículo, por ende la poca biomasa que alcanza (e.g., Rijnsdorp y Witthames 2005).

Las diferencias en la proporción sexual observadas en 4 meses del año podrían deberse al cambio en el uso de hábitat durante los periodos de reproducción y descanso. Este 


\section{Discussion}

Gibson (2008) reported that sexual dimorphism is common in Pleuronectiformes. In this study, A. mazatlanus females were larger than males, a finding also reported by Gibson (2008) and Aguilar-Betancourt et al. (2016). Sexual dimorphism in this species could be the result of males spending more energy on early development and maturation, which is frequent in soles; the larger sizes in females, on the other hand, is related to high fecundity (Roff 1982). Recent studies on the life history of Pleuronectiformes suggest that males can invest little energy in testes maturation, and as a result testes gain less biomass (e.g., Rijnsdorp and Witthames 2005).

The occurrence of sex ratio differences in 4 months of the year could be due to changes in habitat use during the reproductive and resting periods. This behavior was reported by Amezcua-Linares et al. (1992) for A. mazatlanus and is apparently common in Pleuronectiformes (Rijnsdorp and Witthames 2005). However, sex ratio deviated from the 1:1 ratio during periods with less

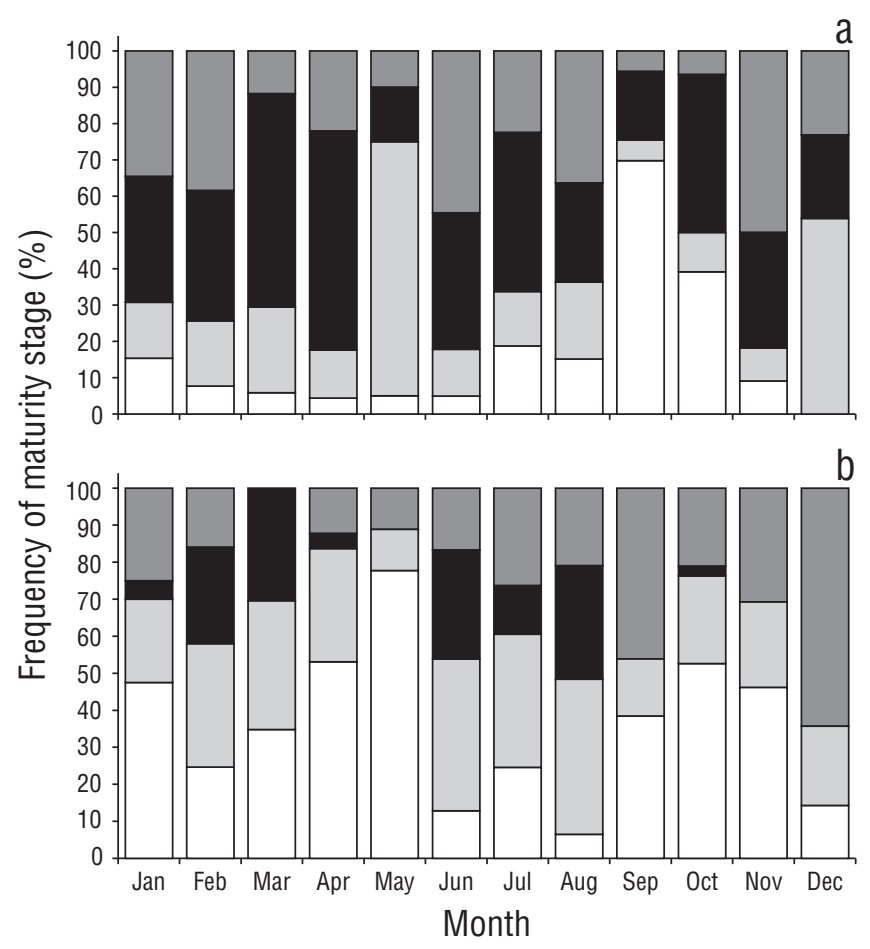

$\square$ Immature $\square$ Developing $\square$ Ripe $\square$ Regressing

Figure 6. Frequency of the 4 stages of gonad development in female (a) and male (b) Achirus mazatlanus in the Barra de Navidad coastal lagoon, Jalisco, Mexico.

Figura 6. Frecuencia de los 4 estadios de madurez gonádica en hembras (a) y machos (b) de Achirus mazatlanus en la laguna costera de Barra de Navidad, Jalisco, México. hecho ha sido reportado por Amezcua-Linares et al. (1992) para A. mazatlanus y, al parecer, es común en los pleuronectiformes (Rijnsdorp y Witthames 2005). No obstante, la proporción sexual difirió de la proporción 1:1 en los periodos con menor actividad reproductiva, y como se capturaron los organismos en toda la laguna, no podemos decir si las diferencias en la proporción sexual mensual se deben a factores reproductivos, a factores fisiológicos o a un uso diferenciado del hábitat (Gibson 2008).

El periodo con mayor actividad reproductiva ocurrió en la temporada de estiaje, en los meses de primavera-verano, lo cual coincide con otros estudios sobre pleuronectiformes (Amezcua-Linares et al. 1992, De Oliveira y Fávaro 2010, De Oliveira y Favaro 2011). Kamler (2002) señaló que la lluvia y el cambio de salinidad pueden ser perjudiciales para el desarrollo de huevos y larvas, y podrían provocar periodos de descanso o reducción de la actividad reproductiva. En el presente estudio, los machos de A. mazatlanus presentaron valores bajos del IGS debido a la poca biomasa de los testículos. Este resultado es de esperarse, ya que los machos de varias especies de pleuronectiformes presentan esta característica (García-López et al. 2005, Rijnsdorp y Witthames 2005, García-López et al. 2006). Debido a la poca variabilidad que presentaron los machos en el IGS, el periodo reproductivo de A. mazatlanus se definió con base en las características observadas en las hembras. Este enfoque es similar al utilizado por Juntti y Fernald (2016), quienes se basaron en las características del ovario para establecer el periodo reproductivo.

Algunas especies de lenguado no modifican de forma significativa su condición corporal para mejorar la calidad de sus gónadas y, por tanto, tampoco la del huevo (Roff 1982). Este comportamiento puede explicar la falta de correlación entre el FC y el IGS en el presente estudio. Además, la condición corporal de los lenguados en sistemas estuarinos depende de los cambios en las comunidades bénticas (Girardin et al. 2016), y es posible que la época de lluvias en la zona no influya en la condición de A. mazatlanus, pero sí en el periodo reproductivo (Amezcua-Linares et al. 1992, De Oliveira y Fávaro 2010).

Se observaron ovarios maduros y ovocitos hidratados en meses con valores bajos del IGS, lo cual puede indicar que en algunas ocasiones las hembras destinan poca energía al desarrollo de las gónadas (McBride et al. 2013). Se encontraron gónadas maduras y desovadas/eyaculadas durante todo el año. Este hallazgo concuerda con la teoría de repartición de apuestas y, a su vez, explica la dominancia de los lenguados en este hábitat, dada la capacidad de adaptación conferida por la estrategia (Simons 2011). El hallazgo también puede sugerir que aunque la especie está catalogada como desovador pelágico, en realidad está desovando dentro de la laguna. El desove en lagunas ya ha sido registrado en otros sistemas estuarinos (Ortíz-Galindo et al. 1990, Silva-Falcão et al. 2012) pero tendría que ser corroborado para la laguna de Barra de Navidad. 
reproductive activity, and since specimens were caught throughout the lagoon, we cannot fully determine if differences in the monthly sex ratios were caused by reproductive factors, physiological factors, or changes in habitat use (Gibson 2008).

The period with the highest reproductive activity occurred during the dry season, in the spring-summer months, a finding that concurs with other Pleuronectiformes studies (Amezcua-Linares et al. 1992, De Oliveira and Fávaro 2010, De Oliveira and Favaro 2011). Kamler (2002) reported that rain and changes in salinity can disrupt egg and larvae development, triggering resting periods or reproductive arrest. In the present study, male A. mazatlanus showed low GSI values because testes biomass was low. This was an expected result because males from many Pleuronectiformes species exhibit this characteristic (García-López et al. 2005, Rijnsdorp and Witthames 2005, García-López et al. 2006). Since male GSI showed little variability, we determined the reproductive period for A. mazatlanus from our observations on female characteristics. This approach is similar to that used by Juntti and Fernald (2016), who used ovarian characteristics to determine the reproductive period.

Some sole species do not significantly change their body condition to improve gonad or, by extension, egg quality (Roff 1982). This behavior could explain the lack of correlation between CF and GSI in the present study. Furthermore, the body condition of soles in estuarine systems depends on changes in benthic communities (Girardin et al. 2016), and though the rainy season in the area might not influence the condition of A. mazatlanus, it does have an effect on its reproductive period (Amezcua-Linares et al. 1992, De Oliveira and Fávaro 2010).

Mature ovaries and hydrated oocytes were observed in months with low GSI values, indicating that females are at times allocating little energy to gonad development (McBride et al. 2013). Mature and spawned/ejaculated gonads were observed throughout the year. This finding is consistent with the bet-hedging theory and, in turn, explains the dominance of soles in this habitat, given the adaptive capacity conferred by this strategy (Simons 2011). This finding could also suggest that, although the species is categorized as a pelagic spawner, it is actually spawning inside the lagoon. Spawning in lagoons has already been recorded in other estuarine systems (Ortíz-Galindo et al. 1990, Silva-Falcão et al. 2012) but would have to be confirmed for the Barra de Navidad Lagoon.

Though high GSI values and periods with maximum oocyte diameters were observed throughout the typical year, paired comparisons did not indicate a defined reproductive period. Nonetheless, in the present study we used other indicators of reproductive activity, such as ovarian wall thickness; this indicator is directly associated with the space occupied by the gonad, since ovarian wall thickness decreases as the muscle stretches with oocyte growth (Behera et al. 2015). Ovarian wall thickness clearly
Aunque se observaron valores altos del IGS y periodos con mayores diámetros de ovocitos a lo largo del año tipo, las pruebas por pares no indicaron un periodo reproductivo definido. No obstante, en el presente estudio se utilizaron otros indicadores de actividad reproductiva, como el grosor de la túnica ovárica; este indicador se relaciona directamente con el espacio que ocupa la gónada, ya que el grosor se reduce debido al estiramiento muscular causado por el incremento en el tamaño de los ovocitos (Behera et al. 2015). El grosor de la túnica ovárica presentó un periodo claro de reducción durante los meses en los que se observaron gónadas maduras y periodos de engrosamiento durante las épocas de descanso y desove. Se observó una correlación negativa entre el grosor de la túnica ovárica y el IGS.

Los valores altos del IGS, el diámetro de los ovocitos, la presencia de gónadas maduras y el adelgazamiento de la túnica ovárica debida a la maduración de los ovocitos, en conjunto, podrían indicar que, a pesar de que A. mazatlanus se puede reproducir durante gran parte del año, la especie presenta un periodo de mayor actividad reproductiva de abril a agosto.

Este estudio presenta por primera vez valores de $\mathrm{L}_{50}$ para A. mazatlanus. Previamente, Amezcua-Linares et al. (1992) mencionaron que la madurez de A. mazatlanus en la laguna Agua Brava, al norte de Nayarit, México, ocurre cuando los individuos alcanzan una longitud de entre 14.0 y $15.9 \mathrm{~cm}$ (no proporcionan un valor específico). La diferencia entre los valores reportados por los 2 estudios puede deberse al sitio de muestreo, a los años de muestreo, al tamaño de muestra y a los diferentes métodos de captura utilizados en el presente estudio, los cuales permitieron cubrir un intervalo más amplio de longitudes. Aunque en los pleuronectiformes la talla de madurez sexual suele ser similar para ambos sexos, los machos tienden a madurar a longitudes ligeramente menores

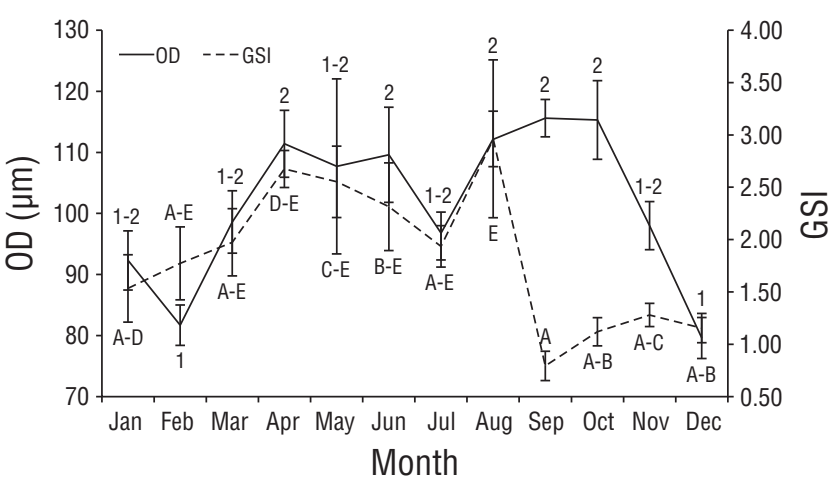

Figure 7. Monthly variation of oocyte diameter (OD) and the gonadosomatic index (GSI) for Achirus mazatlanus in the Barra de Navidad coastal lagoon, Jalisco, Mexico.

Figura 7. Variación mensual del diámetro del ovocito (OD) y del índice gonadosomático (GSI) para Achirus mazatlanus en la laguna costera de Barra de Navidad, Jalisco, México. 
decreased during the months when mature gonads were observed and increased during the resting and spawning seasons. There was a negative correlation between ovarian wall thickness and GSI.

The high GSI values, oocyte diameter, presence of mature gonads, and reduced ovarian wall thickness due to oocyte maturation could all together indicate that, although A. mazatlanus can reproduce throughout most of the year, it exhibits a period with high reproductive activity from April to August.

This study reports $\mathrm{L}_{50}$ values for A. mazatlanus for the first time. In a previous study, Amezcua-Linares et al. (1992) reported that maturity of A. mazatlanus in the Agua Brava Lagoon, north of Nayarit, Mexico, occurs when individuals reach $14.0-15.9 \mathrm{~cm}$ in length (no specific value was provided). The differences between the values reported by both studies could be attributed to the sampling site, sampling years, sample size, and different fishing gears used in the present study, which allowed sampling for a wider length range. Though size at sexual maturity in Pleuronectiformes tends to be similar for both sexes, males tend to mature at slightly shorter lengths than females (Rijnsdorp and Witthames 2005, De Oliveira and Favaro 2011), and this is in agreement with the results reported in the present study.

We did not find any studies describing the macroscopic and microscopic characteristics of A. mazatlanus gonads. Nonetheless, the ovarian characteristics observed for this species during this study coincide with those described for females of other Pleuronectiformes species (Rijnsdorp and Witthames 2005). Achirus mazatlanus gonads exhibited melanomacrophage centers but these centers showed no correlation with the length, time, sex, and gonad maturity variables. Some authors have associated melanomacrophage centers with pathological elements and environmental pollution (Agius and Roberts 2003). Aguilar-Betancourt et al. (2016) analyzed concentrations of stable carbon and nitrogen isotopes in A. mazatlanus tissues and found moderate levels of pollution. It is not clear if these pollution levels are the culprits in the presence of melanomacrophage centers in gonads; we therefore recommend carrying out studies that specifically address this aspect for this species.

The paucity of information on A. mazatlanus stems from the fact that this species has no commercial value. However, because of its generalist habits, abundance, wide distribution, and presence in estuaries and bays, this species is ecologically important. We should not wait for commercial species to collapse to begin studying non-commercial species because habitat degradation is ongoing and can be especially harmful on species whose basic biology and habitat preferences are unknown (Damalas et al. 2010).

\section{ACKNOWLEDGMents}

This study was partly financed by the COECYTJAL-UDG 2010 fund (project no. 05-2010-1-746) and the Apoyo a

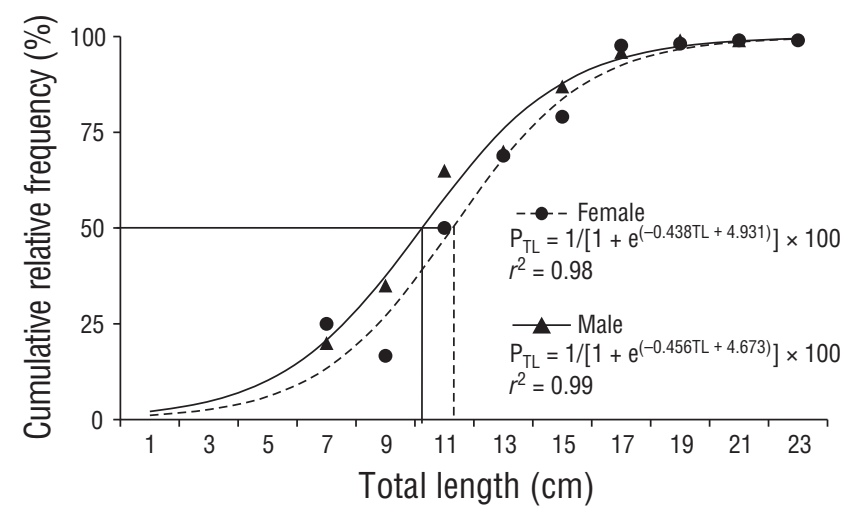

Figure 8. Cumulative relative frequency of mature female and male Achirus mazatlanus in the Barra de Navidad coastal lagoon, Jalisco, Mexico. Values were fit to the logistic equation. TL is total length.

Figura 8. Frecuencia relativa acumulada de hembras y machos maduros de Achirus mazatlanus capturado en la laguna costera de Barra de Navidad, Jalisco, México. Valores ajustados a la ecuación logística. TL es la longitud total.

que las hembras (Rijnsdorp y Witthames 2005, De Oliveira y Favaro 2011), lo que concuerda con los resultados obtenidos en el presente trabajo.

No se encontraron estudios que describan las características macro y microscópicas de las gónadas de A. mazatlanus. Sin embargo, las características de los ovarios de esta especie observadas en este estudio concuerdan con lo descrito para las hembras de otras especies de pleuronectiformes (Rijnsdorp y Witthames 2005). En las gónadas de A. mazatlanus se observaron centros de melanomacrófagos, pero estos no presentaron una relación con las variables longitud, tiempo, sexo y madurez de la gónada. Algunos autores han relacionado a los centros de melanomacrófagos con aspectos patológicos y de contaminación en el ambiente (Agius y Roberts 2003). Aguilar-Betancourt et al. (2016) analizaron la concentración de isótopos estables del carbono y el nitrógeno en tejidos de A. mazatlanus y encontraron niveles moderados de contaminación. No es claro si esos niveles de contaminación son la causa de la presencia de estos cuerpos en las gónadas; por tanto, se recomienda desarrollar otros estudios en esta especie que aborden de manera específica este aspecto.

El escaso conocimiento que se tiene de esta especie se debe a que $A$. mazatlanus no tiene valor comercial. No obstante, sus hábitos generalistas, abundancia, amplia distribución, y presencia en estuarios y bahías le confieren importancia ecológica. No debemos esperar hasta que las poblaciones de peces comerciales colapsen para comenzar a investigar las especies no comerciales, pues la degradación de hábitat es continua y puede tener efectos especialmente perjudiciales sobre las especies al desconocer su biología básica y sus preferencias de hábitat (Damalas et al. 2010). 
Nuevos Profesores de Tiempo Completo (Funding for New Full-time Professors) from the Programa para el Desarrollo Profesional Docente (Professional Teacher Development Program) (file no. 103.5/12/3418). We thank the Marine Biology BSc students at the University of Guadalajara for volunteer work.

English translation by Claudia Michel-Villalobos

\section{REFERENCES}

Agius C, Roberts RJ. 2003. Melano-macrophage centres and their role in fish pathology. J. Fish Dis. 26(9): 499-509. https://doi.org/10.1046/j.1365-2761.2003.00485.x

Aguilar-Betancourt CM, González-Sansón G, Kidd KA, Munkittrick KR, Curry RA, Kosonoy-Aceves D, LucanoRamírez G, Ruiz-Ramírez S, Flores-Ortega JR. 2016. Fishes as indicators of untreated sewage contamination in a Mexican coastal lagoon. Mar. Pollut. Bull. 113(1-2): $100-109$. https://doi.org/10.1016/j.marpolbul.2016.08.073

Aguilar-Palomino B, Pérez-Reyes C, Galván-Magaña F, AbitíaCardenas LA. 2001. Ictiofauna de la Bahía de Navidad, Jalisco, México. Rev. Biol. Trop. 49(1): 173-190. [Accessed 2019 Jun 4]. https://revistas.ucr.ac.cr/index.php/rbt/article/view/16865

Amezcua-Linares F, Castillo-Rodríguez ZG, Álvarez-Rubio M. 1992. Alimentación y reproducción del sol Achirus mazatlanus (Steindachner, 1869) en el sistema lagunar costero de Agua Brava, Pacífico de México. An. Inst. Cienc. Mar. Limnol. 19: 181-194.

Behera S, Kumar S, Devi LM, Gogoi R, Sengar PS, Samanta P, Baksi S, Jomang O. 2015. Determination of seasonal cyclicity of gonad by studying its histology during prespawning and spawning period of Anabas testudineus (Bloch) in natural environment. Int. J. Fish. Aqua. Stud. 2(6): 391-394.

Brown-Peterson NJ, Wyanski DM, Saborido-Rey F, Macewicz BJ, Lowerre-Barbieri SK. 2011. A standardized terminology for describing reproductive development in fishes. Mar. Coast. Fish. 3(1): 52-70. https://doi.org/10.1080/19425120.2011.555724

[CONANP] Comisión Nacional de Áreas Naturales Protegidas. 2008. Programa de conservación y manejo (PCyM) de La laguna Barra de Navidad humedal de importancia internacional. Mexico: CONANP; [accessed 2019 May 22]. http://www. conanp.gob.mx/conanp/dominios/ramsar/docs/sitios/ lineamientos_instrumentos/LAGUNA_BARRA_DE_ NAVIDAD.pdf

Damalas D, Maravelias CD, Katsanevakis S, Karageorgis AP, Papaconstantinou C. 2010. Seasonal abundance of noncommercial demersal fish in the eastern Mediterranean Sea in relation to hydrographic and sediment characteristics. Estuar. Coast. Shelf Sci. 89(1): 107-118.

https://doi.org/10.1016/j.ecss.2010.06.002

De Oliveira EC, Fávaro LF. 2010. Reproduction of the flatfish Achirus lineatus (Pleuronectiformes: Achiridae) in Paranaguá Bay, state of Paraná, a subtropical region of Brazil. Zoologia. 27(4): 523-532. https://doi.org/10.1590/S1984-46702010000400004

De Oliveira EC, Favaro LF. 2011. Reproductive biology of the flatfish Etropus crossotus (Pleuronectiformes: Paralichthyidae) in the Paranaguá estuarine complex,

\section{Agradecimientos}

Esta investigación fue financiada, parcialmente, mediante el fondo COECYTJAL-UDG 2010 (proyecto no. 05-2010-1-746) y el Apoyo a Nuevos Profesores de Tiempo Completo del Programa para el Desarrollo Profesional Docente (oficio: 103.5/12/3418). Agradecemos a los estudiantes de licenciatura de la carrera de biología marina de la Universidad de Guadalajara que participaron como voluntarios.

Paraná State, subtropical region of Brazil. Neotrop. Ichthyol. 9(4): 795-805.

https://doi.org/10.1590/S1679-62252011005000043

Everson AR, Williams HA, Ito BM. 1989. Maturation and reproduction in two Hawaiian Eteline snappers, uku, Aprion virescens, and onaga, Etelis coruscans. Fish. Bull. 87(4): 877-888.

García-López Á, Fernández-Pasquier V, Couto E, Canario AVM, Sarasquete C, Martínez-Rodríguez G. 2006. Testicular development and plasma sex steroid levels in cultured male Senegalese sole Solea senegalensis Kaup. Gen. Comp. Endocrinol. 147(3): 343-351.

https://doi.org/10.1016/j.ygcen.2006.02.003

García-López Á, Martínez-Rodríguez G, Sarasquete C. 2005. Male reproductive system in Senegalese sole Solea senegalensis (Kaup): anatomy, histology and histochemistry. Histol. Histopathol. 20(4): 1179-1189. https://doi.org/10.14670/HH-20.1179

Gibson RN. 2008. Flatfishes: Biology and exploitation. Oxford: Blackwell Science. 391 pp.

Girardin R, Fulton EA, Lehuta S, Rolland M, Thébaud O, Travers-Trolet M, Vermard Y, Marchal P. 2016. Identification of the main processes underlying ecosystem functioning in the Eastern English Channel, with a focus on flatfish species, as revealed through the application of the Atlantis end-to-end model. Estuar. Coast. Shelf Sci. 201: 208-222.

https://doi.org/10.1016/j.ecss.2016.10.016

González-Sansón G, Aguilar-Betancourt C, Kosonoy-Aceves D, Lucano-Ramírez G, Ruiz-Ramírez S, Flores-Ortega JR, Hinojosa-Larios A, Silva-Bátiz FA. 2014. Species and size composition of fishes in Barra de Navidad lagoon, Mexican central Pacific. Int. J. Trop. Biol. 62(1): 129-144.

https://doi.org/10.15517/rbt.v62i1.10001

Gracian-Negrete JM, Del Moral-Flores LF. 2013. Anomalías en algunas especies del género Achirus (Pleuronectiformes: Achiridae). Rev. Zool. 24: 9-15.

Juntti SA, Fernald RD. 2016. Timing reproduction in teleost fish: cues and mechanisms. Curr. Opin. Neurobiol. 38: 57-62. https://doi.org/10.1016/j.conb.2016.02.006

Kamler E. 2002. Ontogeny of yolk-feeding fish: an ecological perspective. Rev. Fish Biol. Fish. 12(1): 79-103. https://doi.org/10.1023/A:1022603204337

Krupp F. 1995. Achiridae. In: Fischer W, Krupp F, Schneider W, Sommer C, Carpenter KE (eds.), Guía FAO para la Identificación de Especies para los Fines de la Pesca. Pacífico Centro-Oriental. Roma: FAO, pp. 845-850.

Lowe-McConnell RH. 1987. Ecological studies in tropical fish communities. England: Cambridge University Press. 382 pp. https://doi.org/10.1017/CBO9780511721892 
Lucano-Ramírez G, Ruiz-Ramírez S, Aguilar-Palomino B, RojoVázquez JA. 2001. Listado de las especies de peces de la región costera de Jalisco y Colima, México. Cien. Mar 5(15): 13-20.

McBride RS, Somarakis S, Fitzhugh GR, Albert A, Yaragina NA, Wuenschel MJ, Alonso-Fernández A, Basilone G. 2013. Energy acquisition and allocation to egg production in relation to fish reproductive strategies. Fish Fisher. 16(1): 23-57. https://doi.org/10.1111/faf.12043

Ortíz-Galindo J, Matus-Nivón E, Ramírez-Sevilla R, GonzálezAcosta B. 1990. Embrión, larva y prejuvenil del sol mexicano Achirus mazatlanus. Rev. Biol. Trop. 38(2A): 195-204.

Robertson DR, Allen GR. 2015. Peces costeros del Pacífico Oriental Tropical: sistema de información en línea. v.2.0. Balboa (República de Panamá): Instituto Smithsonian de Investigaciones Tropicales; [accessed 2019 May 22]. https://biogeodb.stri.si.edu/sftep/es/pages

Rijnsdorp AD, Witthames PR. 2005. Ecology of reproduction. In: Gibson RN (ed.), Flatfishes: Biology and exploitation. Oxford (UK): Blackwell Science, pp. 68-93.
Roff DA. 1982. Reproductive strategies in flatfish: A first synthesis. Can. J. Fish. Aquat. Sci. 39(12): 1686-1698.

Silva-Falcão EC, Severi W, De Araújo ME. 2012. Spatialtemporal variation of Achirus larvae (Actinopterygii: Achiridae) in mangrove, beach and reef habitats in northeastern Brazil. J. Mar. Biol. Assoc. U.K. 93(2): 381-388. https://doi.org/10.1017/S0025315411001706

Simons AM. 2011. Modes of response to environmental change and the elusive empirical evidence for bet hedging. Proc. R. Soc. B-Biol. Sci. 278(1712): 1601-1609. https://doi.org/10.1098/rspb.2011.0176

StatSoft. 2006. Statistica (data analysis software system) v.7.1. https://www.statsoft.com 1 CD-ROM.

Yamamoto K, Yamazaki F. 1961. Rhythm of development in the oocyte of the gold-fish, Carassius auratus. Bull. Fac. Fish. Hokkaido Univ. 12(2): 93-110.

Received January 2019, accepted May 2019. 